DOI: https://doi.org/10.24127/ajpm.v10i3.3214

\title{
EFEK POTENSIAL LEMBAR KERJA SISWA MATEMATIKA MENGGUNAKAN KONTEKS MAKANAN TRADISIONAL TIMOR PADA MATERI PERBANDINGAN
}

\author{
Yohanis Ndapa Deda ${ }^{1 *}$, Talisadika Maifa ${ }^{2}$ \\ ${ }^{1,2}$ Pendidikan Matematika, Fakultas Ilmu Pendidikan, Universitas Timor, Indonesia \\ *Corresponding author. Jl. Eltari, km 09, Kel Sasi, Kota Kefamenanu, TTU, NTT, 85613 \\ E-mail: $\quad$ yndapadeda@gmail.com ${ }^{\left.{ }^{*}\right)}$ \\ talisadikamaifa@unimor.ac.id ${ }^{2}$ )
}

Received 04 November 2020; Received in revised form 20 February 2021; Accepted 29 September 2021

\begin{abstract}
Abstrak
Tujuan penelitian ini adalah untuk mengembangkan LKS matematika SMP yang valid, praktis dan efektif. Penelitian ini penting karena belum pernah ada yang mengembangkan bahan ajar menggunakan kearifan lokal seperti makanan tradisional di Pulau Timor. Makanan Tradisional yang dimaksud dalam penelitian ini adalah Jagung Bose, Jagung Katemak, Ut Kono, dan Laku Tobe yang sudah menjadi makanan sehari-hari masyarakat perbatasan Indonesia-Timor Leste di Pulau Timor. Riset ini ialah riset pengembangan dengan menggunkan model penilaian formatif Tessmer yang terdiri dari 2 sesi pengembangan, yakni ialah sesi analisis pendahuluan serta sesi penilaian formatif. Subjek riset ini merupakan siswa kelas 9 SMPN Taloeb di kawasan perbatasan tahun 2020. Metode pengumpulan informasi yang digunakan meliputi uji hasil belajar, observasi, serta wawancara. Pengembangan lembar kerja siswa memakai konteks kearifan lokal masakan tradisional Timor sudah divalidasi oleh para ahli dengan hasil evaluasi dari pakar materi, pakar media serta pakar bahasa. Validasi oleh para pakar, LKS matematika ini termasuk dalam kategori valid dengan skor rerata 3.97 dan hasil ujicoba telah menunjukkan bahwa LKS tersebut memenuhi kriteria praktis dan memiliki efek potensial untuk meningkatkan hasil belajar matematika siswa SMP hal ini dapat dilihat dari $76.47 \%$ siswa telah mencapai kriteria minimal mata pelajaran matematika tingkat SMP. LKS yang dikembangkan juga efektif karena hasil tes belajar tersebut meningkat dari $41.27 \%$ pada pretest menjadi $76.47 \%$ pada posttest.
\end{abstract}

Kata kunci: Efek Potensial; LKS; Makanan Tradisional

\begin{abstract}
The purpose of this study was to develop valid, practical and effective junior high school mathematics worksheets. This research is important because no one has ever developed teaching materials using local wisdom such as traditional food on the Pulau Timor. The traditional foods referred to in this study are Jagung Bose, jagung Katemak, Ut Kono, and Laku Tobe which have become daily food of the IndonesianTimor Leste border community on Pulau Timor. This research is development research using the Tessmer formative evaluation model are consists of two stages of development, namely the introduction analysis stage and the formative evaluation stage. Data collection techniques used include study results tests Learning outcomes, observations, and interviews. The subject of this study is the 9th graders of Taloeb Junior High School in the border area in 2020. Data collection techniques used include study results tests, observations, and interviews. The development of student worksheets using the context of local wisdom of traditional Timorese food has been validated by experts with assessment results from material experts, media experts and language experts. validation by experts, This math student worksheet belongs to a valid category with an average score of 3.97 and the test results have shown that the student worksheet meets practical criteria and effective criteria. of improving the math learning results of junior high school students. it can be seen from $76.47 \%$ of students who have achieved the minimum criteria for junior high school mathematics. The worksheets developed was also effective because the learning test results increased from $41.27 \%$ in the pretest to $76.47 \%$ in the posttest.
\end{abstract}

Keywords: Potential Effects; Student Worksheets; Traditional Foods

This is an open access article under the Creative Commons Attribution 4.0 International License 
DOI: https://doi.org/10.24127/ajpm.v10i3.3214

\section{PENDAHULUAN}

Amanat Kurikulum 2013 revisi tahun 2017 yang menekankan literasi (budaya), kreativitas, penguatan pendidikan karakter (Amsikan \& Deda, 2020a) dan identitas bangsa dalam proses pembelajaran di sekolah. Salah satu cara menjawab amanat tersebut adalah dengan mengembangkan Lembar Kerja Siswa (LKS) berbasis makanan tradisional masyarakat kawasan perbatasan Indonesia-Timor Leste. LKS ini perlu dikembangkan karena mudah digunakan oleh siswa, menggunakan konteks nyata yaitu makanan tradisonal. Makanan tradisional sebagai salah satu kearifan lokal sangat perlu dilestarikan untuk mempertahankan identitas suku bangsa, juga untuk memperkuat literasi budaya generasi mendatang. Di zaman sekarang dan mendatang, inovasi guru dalam mengembangkan pembelajaran inovatif sangat diperlukan. Inovasi pengembangan teknologi pembelajaran saat ini, seperti pemanfaatan potensi lokal sebagai kearifan lokal dalam pembelajaran matematika (Choirudin, dkk., 2020; Restian, Deviana, \& Saputri, 2020; Amsikan \& Deda, 2018); sangat perlu dilakukan karena faktanya bahwa mata pelajaran matematika masih menjadi mata pelajaran yang sulit bagi sebagian besar siswa, khususnya di kawasan perbatasan. Salah satu alasan adalah pembelajaran matematika di daerah perbatasan belum menggunakan konteks kearifan lokal. Perihal ini bisa dilihat dari Rerata Nilai Ujian Nasional Berbasis Komputer (UNBK) Mata Pelajaran Matematika 2018/2019 tingkat SMP/MTs menunjukkan bahwa Kabupaten Timor Tengah Utara (TTU) mencapai 44,69 di bawah rerata Provinsi NTT 46,29 (Puspendik, 2019).

Penggunakan konteks kearifan lokal dalam pembelajaran matematika diharapkan untuk menciptakan proses pembelajaran yang berbasis kontekstual yang dekat dengan siswa dan juga untuk penguatan karakter siswa (Ikhwanudin, 2018; Amsikan, dkk., 2020a). Penggunakan konteks kearifan juga memiliki peran penting dalam meningkatkan keahlian kognitif siswa (Arisetyawan, 2019). Masuknya konteks makanan tradisional sebagai kearifan lokal dalam kelas akan mebuat siswa berpikir kritis (Muslimahayati, 2020), aktif dan kreatif, suasana menyenangkan (Setyaningsih, Rejeki, \& Ishartono, 2019), mudah memahami materi dan pada akhirnya hasrat serta prestasi belajar siswa meningkat. Pengintegrasian kearifan lokal dalam pembelajaran di kelas, tidak hanya menguntungkan bagi siswa, tetapi juga memberikan kemerdekaan kepada guru untuk mengembangkan dan mendesain bahan ajar sesuai konteks kearifan lokal yang ada di sekitar siswa (Ferdianto \& Setiyani, 2018; Deda \&Amsikan, 2019).

Penelitian ini penting karena menyasar siswa di akawasan perbatasan Pulau Timor. Telebih sekolah tempat dilaksanakan penelitian ini, memiliki rerata UNBK mata pelajaran terendah di kawasan perbatasan. Berpijak dari situasi siswa tersebut, maka kam ingin membantu siswa dengan mengembangkan LKS berbasis makanan tradisional yang dekat dengan kehidupan mereka.

Tujuan riset ini adalah mengembangkan LKS yang menggunakan konteks makanan tradisional di kawasan perbatasan yang sangat dekat dengan kehidupan siswa setaip hari yang valid, praktis dan efektif.

\section{METODE PENELITIAN}

Penelitian ini mengadopsi metode development research dengan tipe penelitian formatif (Ahyan, Zulkardi, \& Darmawijoyo 2014; Disnawati \& Nahak 
2019; Usnul, Johar, \& Sofyan 2019) yang dilaksanakan pada 17 orang siswa kelas 9 SMP Negeri Taloeb. Makanan tradisional yang dimaksud dalam penelitian ini adalah Jagung Bose, Jagung Katemak, Ut Kono, dan Laku Tobe ( Deda \& Disnawati, 2019) yang sudah menjadi makanan sehari-hari masyarakat di kawasan perbatasan.

\section{Tahapan Penelitian}

Penelitian ini dilakukan dalam dua tahap yaitu persiapan yang meliputi analisis kebutuhan siswa dan analisis kurikulum yang diberlakukan pada sekolah tempat penelitian dan tahap formative evaluation meliputi self-evaluation. Pada tahap ini, dilakukan evaluasi secara mandiri oleh pengembang LKS sebelum dievaluasi oleh para ahli dan siswa. Tahap berikutnya adalah prototyping (expert reviews. Pada tahap ini LKS yang dikembangkan diberikan pada para ahli (ahli bahasa, konten, dan desain) untuk divalidasi. Berikutnya adalah tahap one-to-one yang melibatkan tiga orang siswa yang mewakili siswa berkemampuan rendah, sedang, dan tinggi. Tujuan tahap ini adalah mengevaluasi keterbacaan LKS berbasis Makanan tradisional Timor. Selanjutnya adalah tahap uji coba small group, untuk mengevaluasi kepraktisan LKS, tahap ini melibatkan enam siswa yang terdiri dari dua siswa kemampuan rendan, dua siswa sedang, dan dua siswa berkemampuan tinggi. Tahap terhakhir adalah field test. Pada tahap ini dilakukan ujian tes hasil belajar di kelas siswa SMP, untuk melihat potensi efektifitas LKS yang dikembangkan.

Instrumen dalam penelitian ini meliputi soal pretest dan posttest, dokumen LKS yang dikembangkan, kuisioner validator ahli untuk menyatakan kategori kevalidan LKS yang dikembangkan dan pedoman wawancara pada saat uji coba one to one dan ujicoba terbatas.

\section{Teknik Analisis Data}

Teknik analisis data terdiri dari analisis dokumen, analisis walk through, analisis tes, Analisis Pengamatan dan Wawancara.

\section{Analisis Dokumen}

Pada tahap Self-evaluation, analisis dokumen untuk mengetahui apakah LKS yang dikembangkan sesuai dengan tingkat kemampuan siswa dan standar Kurikulum yang berlaku. Hal ini penting dilakukan agar LKS yang dihasilkan pada prototype pertama sesuai dengan apa yang diharapkan dalam penelitian ini. Analisis dokumen pada tahap one to one untuk menganalisis kepraktisan perangkat pembelajaran pada prototype kedua yang diperoleh dari hasil uji coba pada tiga siswa, yaitu berkemampuan tinggi, sedang dan rendah.Hasil analisis ini digunakan untuk merevisi prototype kedua yang kemudian menghasilkan prototype ketiga.Prototype ketiga ini diujicobakan kepada enam siswa yang terdiri dari dua siswa berkemampuan tinggi, dua sedang dan rendah.

\section{Analisis Walk Through}

Analisis pada tahap ini dilakukan setelah hasil Walk Through oleh pakar memberi saran perbaikan dan posisi prototipe serta kesesuaian konteks yang digunakan dalam prototipe tersebut diberikan kembali kepada peneliti. Berdasarkan saran dari para pakar, LKS diperbaiki dan hasilnya adalah LKS yang valid. Analisis tahap ini dilakukan pada prototipe-1 dan kemudian memperoleh prototipe-2.

\section{Analisis Tes}

Data hasil tes yang diperoleh dianalisis berdasarkan kemampuan siswa dilihat dari skor yang diperoleh siswa 
pada pretest dan posttest dalam menyelesaikan soal yang bersesuaian dengan LKS berbasis konteks makanan tradisional.

Analisis Obsevasi dan Wawancara

Data hasil wawancara dianalisis secara deskriptif untuk mengetahui saran dan masukan siswa mengenai kekurangan dan kelebihan LKS yang dikembangkan. Hasil wawancara juga bertujuan untuk melihat bagaimana posisi soal pada prototipe yang dibuat dapat diselesaikan dengan baik dan benar oleh siswa. Kemudian, data hasil observasi dilakukan untuk megetahui tanggapan dan cara berpikir siswa selama proses aktivitas dengan LKS tersebut.

Data kualitatif dari wawancara dan angket dikonversi dengan Skala Likert dengan 5 jawaban seperti Tabel 1. Kriteria pada Tabel 1 digunakan untuk mengkonsul-tasikan hasil skor yang diberikan oleh para ahli pada saat uji validasi dan siswa pada saat uji coba one to one dan ujicoba terbatas.

Tabel 1. Skala Likert

\begin{tabular}{ll}
\hline Skor & Kriteria \\
\hline 5 & Sangat bagus \\
4 & Bagus \\
3 & Cukup \\
2 & Kurang \\
1 & Sangat kurang \\
\hline Penskoran & yang digunakan dalam \\
penilaian validasi ahli dan kepraktisan \\
dari siswa digunakan rumus rata-rata:
\end{tabular}

$$
\bar{x}=\frac{\sum x}{n}
$$

Data wawancara dan angket dari penilaian ahli pada tahap validasi dan penilaian siswa pada tahap uji kepraktisan dikonversikan menjadi data kualitatif berdasarkan Tabel 2 kriteria pengkategorian (Aini, Masykur, \& Komarudin, 2018; Wahyuni, Efuansyah, \& Sukasno 2020).
Tabel 2. Kriteria Pengkategorian

\begin{tabular}{cl}
\hline Interval Skor & Kategori \\
\hline$x>4.5$ & Sangat bagus \\
$3.5<x \leq 4.5$ & Bagus \\
$2.3<x \leq 3.5$ & Cukup bagus \\
$1<x \leq 2.3$ & Tidak bagus \\
\hline
\end{tabular}

\section{HASIL DAN PEMBAHASAN}

Tahap pertama dalam penelitian ini adalah tahap persiapan, yaitu melakukan survey tentang makanan tradisional yang ada di Pulau Timor sebagi kearifan lokal yang ada di kawasan perbatasan dan melihat aktivitas matematika yang terjadi dalam proses pembuatan makanan tradional, bentuk makananan tradisional. Menganalisis silabus dan kurikulum 2013 revisi tahun 2017 pada mata pelajaran matematika SMP. Kemudian tahap kedua, yaitu tahap formatif evaluation yang terdiri dari self-evaluation, validasi ahli, ujicoba one to one, ujicoba terbatas, dan ujicoba lapangan self evaluaton, yaitu kami merancang dan mmperbaiki sendiri LKS mata pelajaran matematika SMP berbasis makanan tradional di kawasan perbatasan. LKS hasil self evaluatin ini dinamakan protopype 1. Pada tahap Validasi ahli, LKS matematika menggunakan konteks makanan tradional laku tobe, ut kono, jagung bose dan jagung katemak dinilai oleh tiga orang ahli yaitu satu orang Dosen Pendidikan Matematika sebagai ahli media, satu orang guru matematika SMP di kawasan perbatasan IndonesiaTimor Leste sebagai ahli konten/materi dan satu orang Dosen Pendidikan Bahasa dan Sastra Indonesia sebagai ahli bahasa. Tabel 3 berikut ini adalah hasil evaluasi akhir dari masing-masing ahli. Pada tahap uji coba one to one, LKS diujikan kepada tiga siswa yang mewakili kemampuan tinggi, sedang dan rendah. Tujuan pada tahap ini adalah untuk mengecek keterbacaan LKS yang 
dikembangkan bila ada yang kekurangan pada tahap validasi. Selanjutnya ujicoba terbatas yang bertujuan untuk menguji tingkat kesukaran soal-soal pada LKS yang dikembangkan. Pada tahap ini, LKS diujicobakan pada 6 (enam) siswa yang terdiri dari 2 siswa berkemampuan tinggi, 2 siswa sedang dan 2 siswa berkemampuan rendah. Setelah dilakukan ujicoba terbatas, LKS yang dikembangkan disempurnakan untuk digunakan pada tahap selanjutnya, yaitu ujicoba lapangan. Pada uji coba lapangan, LKS diujikan secara klasikan atau kelas besar. Tujuannya untuk melihat tingkat efektifitas LKS yang dikembangkan. Contoh hasil LKS yang telah dikembangkan seperti terlihat pada Gambar 1.

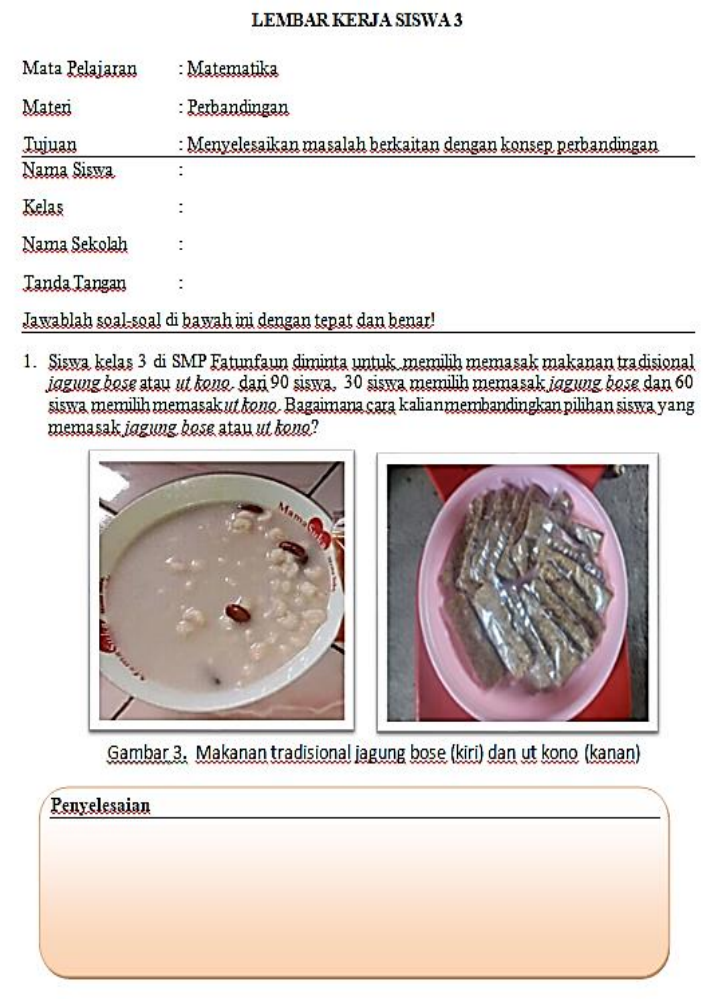

Gambar 1. Contoh LKS Perbandingan menggunakan konteks kearifan lokal.
Tabel 3. Rekapitulasi penilaian validator

\begin{tabular}{lllll}
\hline Validator & $\begin{array}{c}\text { Jumlah } \\
\text { item }\end{array}$ & $\begin{array}{c}\text { Skor } \\
\text { yang } \\
\text { didapat }\end{array}$ & $\begin{array}{c}\text { Rerata } \\
\text { skor }\end{array}$ & Kategori \\
\hline $\begin{array}{l}\text { Ahli Materi/ } \\
\text { content }\end{array}$ & 25 & 105 & 4.2 & Valid \\
Ahli Media & 18 & 69 & 3.83 & Valid \\
Ahli Bahasa & 9 & 35 & 3.88 & Valid \\
\hline \multicolumn{1}{c}{ Total } & $\mathbf{5 2}$ & $\mathbf{2 0 9}$ & $\mathbf{3 . 9 7}$ & Valid \\
\hline
\end{tabular}

Tabel 4. Komentar dan saran validator

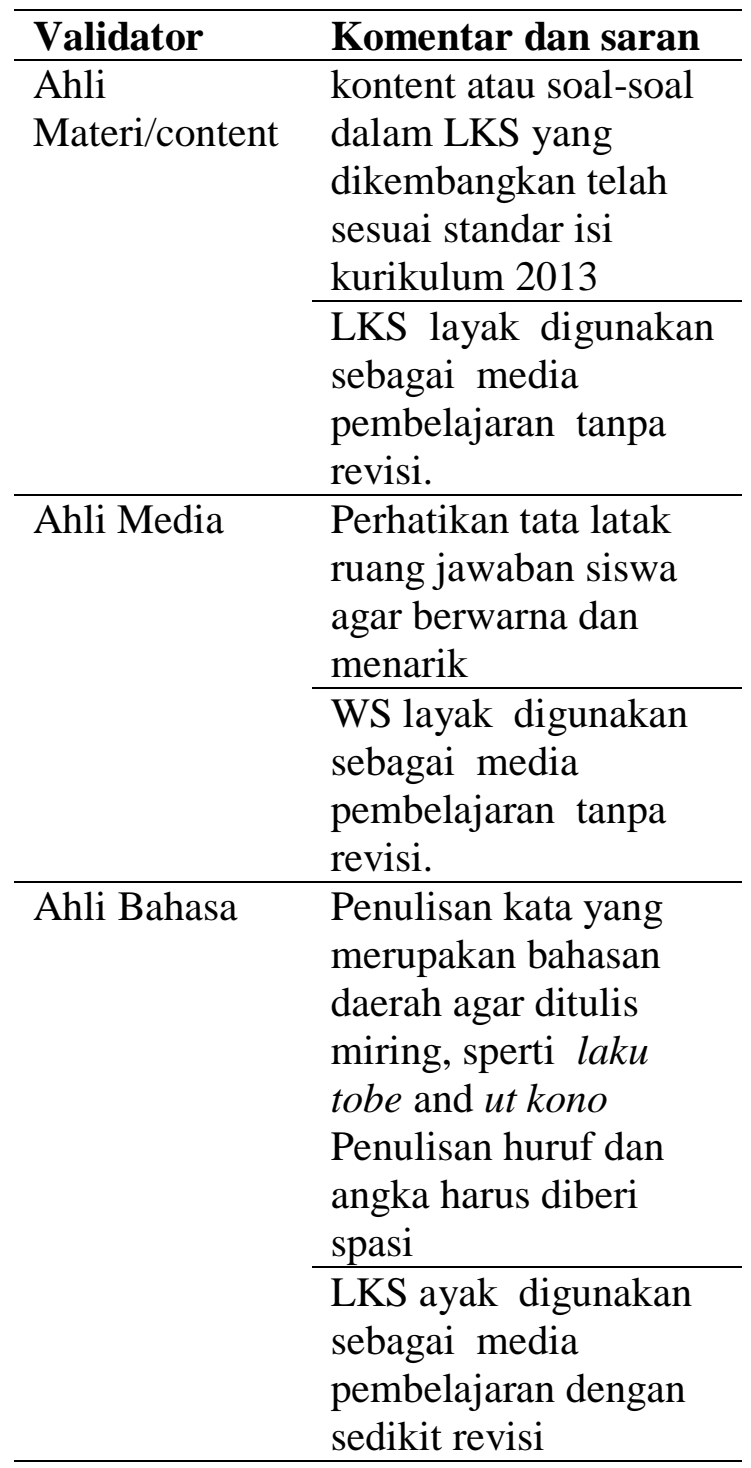

Setelah melakukan revisi sesuai komentar dan saran para ahli pada Tabel 4. Pada tahap validasi ahli ini, diperoleh prototype 2, LKS matematika menggunakan konteks makanan tradisional yang valid berdasarkan 
DOI: https://doi.org/10.24127/ajpm.v10i3.3214

rekapitulasi penilaian para ahli pada Tabel 3.

\section{Tahap uji coba one to one dan ujicoba terbatas}

Pada tahap ini, kami ingin memperoleh tanggapan dan masukan dari siswa tentang LKS yang dikembangkan. Sebelum melakukan uji coba one to one, kami mengumpulkan informasi siswa kelas tiga salah satu SMP di Kabupaten Timor Tengah Uatara. informasi ini digunakan untuk mengetahui siswa yang berkemampuan rendah, sedang dan tinggi. Tahap uji coba satu-satu tidak dilakukan secara simultan dengan tahap validasi ahli (Amsikan \& Deda, 2020b; Deda \& Disnawati, 2019). Pertimbangannya adalah karena pada tahap ini, selain siswa memberi pandangan atau masukan tentang LKS yang dikembangkan, tahap uji coba satu-satu juga dimaksudkan untuk mengidentifikasi, mengecek kembali bilamana ada kemungkinan kekeliruan LKS yang luput dari perhatian para ahli seperti tanda baca, bahasa yang salah dan petunjuk yang kurang jelas.

Tabel 5. Komentar dan saran mahasiswa pada tahap one to one

\begin{tabular}{|c|c|c|c|}
\hline No & Nama siswa & Komentar dan saran siswa & $\begin{array}{c}\text { Tanggapan } \\
\text { peneliti }\end{array}$ \\
\hline 1 & $\begin{array}{l}\text { UJS1 } \text { (Mewakili } \\
\text { siswa berkemampuan } \\
\text { rendah) }\end{array}$ & $\begin{array}{l}\text { Soal-soal yang ada di dalam LKS } \\
\text { mudah di pahami dan tampilannya } \\
\text { menarik }\end{array}$ & $\begin{array}{l}\text { Diterima } \\
\text { komentar dan } \\
\text { sarannya }\end{array}$ \\
\hline 2 & $\begin{array}{l}\text { UJS2 (Mewakili } \\
\text { siswa berkemampuan } \\
\text { sedang) }\end{array}$ & $\begin{array}{l}\text { Soal-soal yang ada di dalam LKS } \\
\text { sangat jelas, gambar sangat sesuai } \\
\text { karena menggunakan makanan } \\
\text { tradisional }\end{array}$ & $\begin{array}{l}\text { Diterima } \\
\text { komentar dan } \\
\text { sarannya }\end{array}$ \\
\hline 3 & $\begin{array}{l}\text { UJS3 } \text { (Mewakili } \\
\text { siswa berkemampuan } \\
\text { tinggi) }\end{array}$ & $\begin{array}{l}\text { Soal-soalnya menarik, mudah untuk } \\
\text { kerjakan. }\end{array}$ & $\begin{array}{l}\text { Diterima } \\
\text { komentar dan } \\
\text { sarannya }\end{array}$ \\
\hline
\end{tabular}

Keterangan, UJS1 = uji coba siswa pertama.

Berdasarkan hasil uji coba one to one pada Tabel 5 dan wawancara langsung dengan tiga siswa terlihat siswa UJS1, UJS2 dan UJS3 tidak mengalami kesulitan dalam memahami soal-soal yang ada dalam LKS, siswa tersebut mengerti karena konteks yang digunakan adalah makanan tradisonal yang juga makanan siang malam dan semua siswa di sekolah tempat ujicoba bahan ajar ini adalah penduduk asli di kawasan perbatasan Pulau Timor.
Pada saat wawancara siswa mengungkapkan bahwa siswa lebih mudah memahami masalah sehari-hari yang berkaitan dengan perbandingan. Contoh, ketika ditanyakan bagaimana mebandingkan siswa yang suka masak jagung bose dengan ut kono (soal nomor pada LKS). Siswa yang berkemampuan sedang dan tinggi bias menjawabnya dengan benar. Sedangkan sebelumnya mereka kesulitan memahami soal-soal cerita yang ada 
dalam buku pelajaran yang kurang kontekstual. Hasil uji coba satu-satu adalah prototype 3 yaitu LKS yang terbaca dan telah mendapat saran dari siswa.

Tahap uji coba terbatas (small group) untuk mendapatkan pandangan dari siswa terkait LKS matematika menggunakan konteks makanan tradisonal Pulau Timor yang dikembangkan.Pada tahap ini melibatkan 6 siswa, yaitu 2 siswa berkemampaun rendah, dua siswa berkemampuan sedang dan dua siswa berkemampuan tinggi. Hasil uji coba kelas kecil ini menunjukkan bahwa LKS berbasis makanan tradisonal Pulau Timor dapat diterima dan dapat digunakan dengan baik. Hal ini dapat dilihat dari hasil pekerjaan siswa yang telah mampu mengerjakan soal-soal dalam LKS. Hasil wawancara juga menunjukkan bahwa siswa berkemampuan rendah, sedang dan tinggi tidak mengalami kesulitan berarti dalam menyelesaikan soal pada LKS berbasis kearifan lokal. Siswa berkemampuan rendah mengalami kesulitasn mngerjakan soal nomor 3 yang diketahui harga $3 \mathrm{~kg}$ jagung kuning dan ditanya harga $8 \mathrm{~kg}$ jagung kuning. Tetapi setelah melakukan pendampingan siswa tersebut memahami dan bisa menyelesaikan soal tersebut. Hasil wawancara dari semua siswa yang berkemampuan tinggi, sedang dan rendah menunjukkan bahwa pada awalnya mereka kesulitan memahami soal-soal yang mengukur literasi matematika. Hal ini diakibatkan karena soal-soal tersebut merupakan soal-soal berkategori high order thinking skills (Deda, dkk, 2020) untuk mengukur keterampilan berpikir kritis seperti menganalisis, evaluasi, mencipta, menalar, dan membuat keputusan. Namun setelah pembelajaran menggunakan LKS berbasis makanan tradisional, mereka bias mengikuti materi dengan baik dan bahagia. Pada tahap ini diperoleh gambaran bahwa soal-soal yang ada dalam LKS yang menggunakan koteks makanan tradisional telah menolong siswa untuk memahami materi perbandingan dengan baik. Sebelum adanya LKS ini, mereka kesulitan memahami penerapan konsep perbandingan dalam kehidupan seharihari. Masukan dari siswa berkemampuan rendah dijadikan bahan untuk merevisi LKS berbasis makanan tradisional yaitu prototype 4 agar memenuhi criteria praktis.

\section{Uji coba lapangan}

Pada tahap ini, produk LKS terakhir atau prototype 4 diujicobakan kepada siswa kelas tiga SMP di salah satu SMP yang memiliki rata-rata hasil UNBK mata pelajaran matematika tahun 2019 terendah di Kabupaten Timor Tengah Utara. Peserta pada tahap uji lapangan diikuti 17 peserta yang terlibat karena mengikuti protokol kesehatan Pandemi virus corona (Covid19) pada saat berlangsugnya penelitian ini. Indikator soal pada Prototipe keempat ini adalah menyelesaikan masalah nyata yang bersesuaian dengan operasi bilangan bulat dan bilangan pecahan.LKS berbasis makanan ini merupakan hasil uji coba satu-satu dan uji coba terbatas, sehingga jumlah butir soal yang sesuai dengan kemampuan siswa di kawasan tersebut adalah 5 butir soal pada LKS tersebut yang terbukti praktis dan sesuai kemampuan siswa.Hasil Pretest siswa sebelum pembelajaran menggunakan LKS matematika berbasis makanan tradisional sebagai kearifan lokal dapat dilihat pada Tabel 6 . 
DOI: https://doi.org/10.24127/ajpm.v10i3.3214

Tabel 6. Hasil Pretest dan Postest siswa

\begin{tabular}{cccccc}
\hline $\begin{array}{c}\text { Rentang Nilai } \\
\text { Siswa }\end{array}$ & \multicolumn{2}{c}{ Jumlah Siswa } & \multicolumn{2}{c}{ Persentase } & Kategori \\
\hline & Pretest & Posttest & Pretest & Posttest & \\
\hline $80-100$ & - & 2 & - & $11.76 \%$ & Tercapai \\
$70-79$ & 2 & 3 & $11.76 \%$ & $17.65 \%$ & Tercapai \\
$60-69$ & 5 & 8 & $29.41 \%$ & $47.06 \%$ & Tercapai \\
$50-59$ & 7 & 3 & $41.18 \%$ & $17.65 \%$ & Tidak Tercapai \\
$40-49$ & 3 & 1 & $17.65 \%$ & $5.88 \%$ & Tidak Tercapai \\
\hline Jumlah & 17 & 17 & $100 \%$ & $100 \%$ & \\
\end{tabular}

Hasil pretest dan post-test pada tabel 6 menunjukkan bahwa dari 17 siswa yang mengikuti pre-test sebelum pembelajaran menggunakan LKS berbasis makanan tradisional terdapat $58.73 \%$ siswa belum mencapai kriteria ketuntasan pembelajaran yang ditetapkan oleh SMP tersebut. Akan tetapi setelah siswa menggunakan LKS dalam pembelajaran, tes hasil belajar (THB) pada saat posttest seperti tabel 5 menunjukkan bahwa $23.53 \%$ siswa yang belum mencapai kriteria. Artinya LKS yang dikembangkan telah memenuhi kriteria efektif. Hal ini berarti LKS yang dikembangkan telah menunjukkan efek potensial karena $76.47 \%$ siswa telah mencapai kriteria minimal mata pelajaran matematika. Ini berarti bahwa penggunaan kearifan lokal dapat membawakan pengaruh positif kepada siswa (Zulfah, 2018). Berdasarkan angket yang disebar setelah siswa mengikuti THB bahwa siswa merasa senang dan termotivasi dengan pembelajaran yang menggunakan kearifan lokal (Dazrullisa, 2018) sebagai konteks yang dapat memudahkan untuk memahami materi perbandingan. Siswa merasa terbantu karena mereka lebih mudah memahami materi perbadingan yang sebelumnya mereka anggap sulit. Siswa merasa percaya diri karena jawaban yang mereka ajukan diterima. Karena soal-soal perbandingan dalam LKS, seperti soal nomor 3, siswa harus membuat keputusan untuk membeli ut kono diantara toko Biinmafo Mart dan Afenpah Mart. Demikian pula soal nomor 2, siswa memikirkan caranya sendiri meberikan argument tentang perbandingan jumlah siswa yang memilih memasak jagung bose dengan ut kono. Pemahaman siswa akan konsep perbadingan lebih baik dengan menggunakan konteks makanan tradisional yang dekat dengan mereka. Walau dalam situasi Pandemi Covid-19, pemahaman atau keterampilan matematika siswa tetap meningkat, dapat dilihat dari jumlah siswa yang tuntas pada pretest hanya 7 siswa dan pada posttest menjadi 13 siswa. Hasil penelitian ini terlihat bahwa dengan menggunakan Kearifan lokal dalam pembelajaran matematika dapat meningkatkan pemahaman dan menjadi pintu masuk siswa memahami mata pelajaran matematika (Deda \& Maifa, 2021; Heriyadi \& Prahmana, 2020). 
Produk yang dihasilkan mulai dari tahap persiapan hingga evalusi formatif adalah diperolehnya satu set LKS menggunakan makanan tradisional laku tobe, ut kono, jagung bose dan jagung katemak sebagai kearifan lokal yang valid, praktis dan memiliki efek potensial meningkatkan hasil belajar matematika. Hasil dan temuan ini sesuai dan sejalan dengan penelitian terdahulu (Deda \& Maifa 2021; Heriyadi and Prahmana 2020; Amsikan \& Deda 2020b; Deda \& Disnawati, 2019). Siswa di kawasan perbatasan sangat antusias dalam pelaksanaan penelitian ini karena menggunakan konteks nyata dalam kehidupan sehari-hari mereka.

Berdasarkan uraian pada bagian pembahasan ini, maka yang menjadi keunggulan dalam penelitian ini adalah hasil tes belajar siswa yang memiliki nilai UNBK terendah pada mata pelajaran matematika meningkat. Peningkatan ini disebabkan karena penggunaan konteks makanan tradisonal Pulau Timor yang sangat dekat dengan kehidupan siswa di salah satu SMP Negeri di kawasan perbatasan Indonesia-Timor Leste.

\section{KESIMPULAN DAN SARAN}

Berdasarkan hasil dan pembahasan yang telah diuraikan, maka dapat disimpulkan bahwa LKS matematika menggunakan konteks makanan tradisional laku tobe, ut kono, jagung bose dan jagung katemak yang dikembangkan untuk siswa SMP di kawasan perbatasan Indonesia-Timor Leste telah meningkatkan keterampilan dan hasil belajar mata pelajaran matematika pada materi perbandingan. Kriteria valid, praktis dan efektif juga telah dipenuhi. Kami menyarankan agar pengembangan LKS ini dilanjutkan dengan mengembangkannya menjadi LKS audio visual.

\section{UCAPAN TERIMA KASIH}

Kami berterima kasih kepada Ristek BRIN dan LPPM Universitas Timor, SMPN Taloeb yang telah mendukung terlaksananya penelitian dosen pemula (PDP) ini.

\section{DAFTAR PUSTAKA}

Ahyan, S., Zulkardi, \& Darmawijoyo. (2014). Developing Mathematics Problems Based on Pisa Level of Change and Relationships Content. Journal on Mathematics Education 5(1), 47-56. doi: 10.22342/jme.5.1.1448.47-56.

Aini, E. P., Masykur, R., \& Komarudin, K. (2018). Handout Matematika Berbantuan Etnomatematika Berbasis Budaya Lokal. Desimal: Jurnal Matematika 1(1), 73-79. doi: 10.24042/djm.v1i1.1950.

Arisetyawan, A. (2019). Pentingnya Pembelajaran Etnomatematika Dalam Meningkatkan Kemampuan Kognitif Siswa Dan Bagaimana Mendisain Bahan Ajar Berbasis Kearifan Lokal. Jurnal Basicedu 3(2), 21-26. doi: 10.31004/basicedu.v3i2.47.

Ningsih, E. F., Anwar, M. S., Sari, I. R., \& Amalia, S. (2020). Pengembangan Perangkat Pembelajaran Etnomatematika Pada Situs Purbakala Pugung Raharjo. $\quad P i$ : Mathematics Education Journal, 3(1), 18-27. doi: 10.21067/pmej.v3i1.3755.

Dazrullisa. (2018). Pengaruh Pembelajaran Matematika Berbasis Kearifan Lokal Terhadap Minat Belajar Siswa. Genta Mulia, 9(2), 141-49.

Deda, Y. N., \& Maifa T. 2021. Development of Student Worksheets Using the Context of Local Wisdom on Integers and Fractions. Jurnal Pendidikan 
DOI: https://doi.org/10.24127/ajpm.v10i3.3214

Matematika, 15(1), 71-82. doi: 10.22342/jpm.15.1.12824.71-82.

Deda, Y. N., Ratu, A. H., Amsikan, S., \& Mamoh, O. (2020). Analisis Kemampuan Siswa Dalam Menyelesaikan Soal Ujian Nasional Matematika SMP/MTS Berdasarkan Perspektif Higher Order Thinking Skills (Hots). JUPITEK: Jurnal Pendidikan Matematika, 3(1), 1-6. doi: 10.30598/jupitekvol3iss1pp1-6.

Disnawati, H., \& Nahak, S. (2019). Pengembangan Lembar Kerja Siswa Berbasis Etnomatematika Tenun Timor Pada Materi Pola Bilangan. Jurnal Elemen, 5(1), 6479. doi: 10.29408/jel.v5i1.1022.

Ferdianto, F., \& Setiyani, S. (2018).

Pengembangan Bahan Ajar Media Pembelajaran Berbasis Kearifan Lokal Mahasiswa Pendidikan Matematika. JNPM (Jurnal Nasional Pendidikan Matematika), 2(1), 37-47. doi: 10.33603/jnpm.v2i1.781.

Heriyadi, H., \& Prahmana, R. C. I. (2020). Pengembangan Lembar Kegiatan Siswa Menggunakan Pendekatan Pendidikan Matematika Realistik. AKSIOMA: Jurnal Program Studi Pendidikan Matematika, 9(2), 395-412. doi: 10.24127/ajpm.v9i2.2782.

Ikhwanudin, T. (2018). Pembelajaran Matematika Berbasis Kearifan Lokal Untuk Membangun Karakter Bangsa. UNION: Jurnal Ilmiah Pendidikan Matematika, 6(1), 1118. doi: 10.30738/.v6i1.1560.

Muslimahayati. (2020). Pengembangan Soal Kemampuan Berpikir Kritis Berbasis Kearifan Lokal Sumatera Selatan Pada Materi Trigonometri. AKSIOMA: Jurnal Program Studi Pendidikan Matematika, 9(1), 12. doi: 10.24127/ajpm.v9i1.2459.
Pusat Penilaian Pendidikan (Puspendik) Kementerian Pendidikan dan Kebudayaan. (2019). Laporan Hasil Ujin Nasional SMA/MA Tahun Ajaran 2018/2019. 1.

Restian, A., Deviana, T., \& Saputri, Y. N. E. (2020). Pengembangan LKS Berbasis Kearifan Lokal Di Malang Untuk Siswa Kelas IV SD. Scholaria: Jurnal Pendidikan Dan Kebudayaan, 10(1), 85-91. doi: 10.24246/j.js.2020.v10.i1.p85-91.

Setyaningsih, N., Rejeki, S., \& Ishartono, N. (2019). Developing Realistic and Child-Friendly Learning Model for Teaching Mathematics. JRAMathEdu (Journal of Research and Advances in Mathematics Education), 4(2), 79-88. doi: 10.23917/jramathedu.v4i2.8112.

Amsikan S., \& Deda, Y.N. (2018). Memanfaatkan Potensi Lokal Kefamenanu Dalam Pembelajaran Matematika Untuk Meningkatkan Kreativitas Guru SMP. Bakti Cendana 1(1), 32-40. doi: 10.32938/bc.v1i1.17.

Amsikan S., \& Deda, Y.N. (2020a). Penguatan Pendidikan Karakter Dalam Pembelajaran Matematika Dengan Menggunakan Motif Kain Tenun Insana Strengthening of Character Education in Mathematics Learning Using Insana Motif of Woven Fabric 1). JPPM ,4(1), 25-30.

Amsikan S., \& Deda, Y.N.( 2020b). The Development of Etnomathematics Teaching Materials Using Ume Kbubu Context on Students of Mathematics Education Department. International Journal of Trends in ... 3(2), 96-100.

Usnul, U., Johar, R., \& Sofyan, H. (2019). Potential Effect of PISA Equivalent Questions Using the 
DOI: https://doi.org/10.24127/ajpm.v10i3.3214

Context of Aceh Traditional Houses. JRAMathEdu (Journal of Research and Advances in Mathematics Education), 4(2), 89100. doi: 10.23917/jramathedu.v4i2.8362.

Wahyuni, R., Efuansyah, E., \& Sukasno, S. (2020). Developing Student Worksheet Based on Missouri Mathematics Project Model By Using Think-Talk-Write Strategy of Class Viii. Infinity Journal, $\quad 9(1), \quad 81$. doi: 10.22460/infinity.v9i1.p81-92.

Deda Y.N., \& Disnawati H. (2019). Buku Ajar Etnomatematika Kawasan Perbatasan NKRI-Timor Leste. Yogyakarta: Deepublish.

Deda Y.N., \& Disnawati H. (2019). Pengembangan Lembar Kerja Mahasiswa (Lkm) Etnomatematika Menggunakan Konteks Motif Kain Tenun Timor. Jurnal Karya Pendidikan Matematika, 6(2), 2026.

Deda Y.N., \& Amsikan S. (2019). Geometry Concept on the Motifs of Woven Fabric in Kefamenanu Community. JRAMathEdu (Journal of Research and Advances in Mathematics Education), 4(1), 23-30. doi: 10.23917/jramathedu.v4i1.6253.

Zulfah. (2018). Analisis Kebutuhan Pengembangan Soal Berbasis Kearifan Lokal. Jurnal Cendekia: Jurnal Pendidikan Matematika, 2(1), 1-6. doi: 10.31004/cendekia.v2i1.27. 